\title{
FAILURE PREDICTION FROM THE INVESTORS' VIEW BY USING FINANCIAL RATIOS. LESSON FROM ROMANIA
}

\author{
Monica Violeta Achim, Sorin Nicolae Borlea, \\ Lucian Vasile Găban
}

\section{Introduction}

The economy's globalization which culminated with the global financial crisis that erupted in 2007 has affected the economies around the world demonstrating that the results of research studies on bankruptcy risk prediction are insufficient. Furthermore, the studies conducted so far do not provide direct insight into the capital market to investors for whom the first step in a company's failure is manifested by delisting the company from the stock exchange. According with Altman (1968) "in the case of listed companies, in a 4 days interval before announcing bankruptcy, investors lose about $41 \%$ of the capital invested in bankrupt companies." The ability to predict the companies' bankruptcy from the early stage of delisting is the main novelty of the present study.

In the specialized literature there are relatively few concerns about bankruptcy's risk prediction from the investor's perspective. Most studies evaluating the bankruptcy risk were structured to approach bankruptcy from a "legal" perspective according to which companies were grouped into failing companies (for which there is a statement in this regard at the court) and the other group consists of nonbankrupt companies. There is though, another group of studies which analyse bankruptcy risks from an "economic" perspective according to which the companies were grouped into failing companies (represented by companies with low financial and economic performance) and non-bankrupt companies (represented by companies that have different performance indicators considered to be high). An even fewer number of studies are focused (in the economic approach) on the investors' angle, according to which companies become bankrupt beginning with the delisting phase (Christidis \& Gregory, 2010; Tuvadaratragool, 2013; Wang \& Campbell, 2010).

Our paper has the following main objectives: First of all, we aim to identify which financial indicators have a significant impact on the probability of a company to face bankruptcy risks expressed from the investors' perspective by studying the impact on the prospects of stocks' delisting from the stock exchange.

Secondly, we would like to determine to what extent are these indicators identified in other studies as significant bankruptcy signs. Is there any difference between the indicators identified as having a major impact from the investors' perspective compared to the general one?

The paper is structured as follows. In the next section (Section 1) we present a review of the literature in terms of bankruptcy risk where the "failure" concept is presented, we present the importance given to financial rates in bankruptcy risk studies highlighting the main methods used in bankruptcy's risk analysis and finally we emphasize the time and space limits of failure prediction models that exist in the literature. Section 2 refers to the general presentation of the elaboration methodology. Further, Section 3 is dedicated to the description of the obtained empirical results, their alignment to other empirical findings and to highlighting the changes in bankruptcy predictors. The last part of the paper (Conclusions) is allocated to describing the conclusions and to highlighting the added value of this study in order to cover some gaps in the niche of developing some bankruptcy risk models from the perspective of the capital market investors. 


\section{Literature Review}

\subsection{On the "Failure" Concept}

Firstly it is necessary that we clarify the term of "failure". Investigating the studies on bankruptcy risk, we can conclude that corporate "failure" is approached from two perspectives: a legal one and an economic one.

Under a legal aspect, a company's bankruptcy occurs when there is a strong bankruptcy statement in a court. For US an ailing firm might file either for liquidating its assets or for business reorganisation (Altman \& Hotchkiss, 2006). According to Balcaen and Ooghe (2006) the most studies used 'legal' interpretations of the relevant terms because of the objective's perspective to discriminate failed and non-failed firms. Among these studies we can mention the following: Anghel (2002), Altman (1968), Beaver, McNichols and Rhie (2005), Chi and Tang (2006), Platt and Platt (1990; 1991; 2008), Shumway (2001).

Under an economic aspect, a failure can be defined through the company's financial performance that can be represented by:

- "Insufficient revenues to cover costs and where the average return on investment is below the firm's cost of capital" (Altman \& Hotchkiss, 2006);

- "negative equity and/or negative earnings" (Robu-Mironiuc, 2012; Tuvadaratragool, 2013);

- "reductions in dividends, violations of debt covenants" (Tuvadaratragool, 2013);

- "going private for a publicly listed company" which is similar to delisting the companies' shares (Christidis \& Gregory, 2010; Ohlson,1980; Tuvadaratragool, 2013; Wang \& Campbell, 2010).

On the other hand, there are various studies which opt for "economic" interpretation when determining the two types of companies: bankrupt or non-bankrupt; as follows: Beaver (1966; 2005), Christidis and Gregory (2010), Ohlson (1980), Robu-Mironiuc (2012), Tuvadaratragool (2013), Wang and Campbell (2010).

According to Altman and Hotchkiss (2006) four common terms are widely used in bankruptcy studies, namely: failure, insolvency, default and bankruptcy. We can add here the term of "financial distress" which is similar with the economic failure (Tuvadaratragool, 2013) which means that the company has financial problems but is not in bankruptcy yet.
As we can see, there are a wide range of applications of the term "failure", according to the specific objectives of each study and the specific needs of various decision-makers. In this paper, the concept of corporate "failure" is used from the investors' perspective, for whom the delisting of the company from the stock market is synonymous with bankruptcy itself because their investment is compromised, a trading platform wouldn't be existing anymore (Wang \& Campbell, 2010). In other words, in our study, both business "failure" and "delisting" are used interchangeably.

\subsection{The Role of Financial Indicators in Predicting the Financial Distress}

The international accounting regulation consists in International Financial Reporting Standards. The financial statements' objective is to provide information about the financial position, performance and changes in the entity's financial position that are useful to a wide range of users in making economic decisions. It goes without saying that the financial information from the financial and accounting status is designed to highlight the company's financial condition.

Moreover, several studies conducted by Beaver, Correia and McNichols (2010) highlight that "the financial statements have been used for more than 100 years to assess financial distress' likelihood". From the financial information's category, financial rates are the most commonly used in bankruptcy risk assessment because it is believed that their use compared to that of the indicators' absolute levels provides a general degree of applicability for the companies. By using financial ratios, the limits generated by the companies' size are thereby significantly reduced.

The preference of using financial rates in bankruptcy risk assessment has been manifested since the studies of Beaver (1966) and Altman (1968). In his univariate analysis, Beaver (1966) identified the cash flow indicator to total debt ratio to be extremely sensitive for a company's financial condition. Subsequently, Altman (1968) introduced the multivariate analysis and identified five representative financial ratios for the financial condition: working capital/total assets; total retained earnings/total assets; earnings before interest and taxes/total assets; market value of equity / book value of total debt; sales/total assets. 
Another pioneer of bankruptcy risk assessment namely Ohslon (1980) introduced the Logit model in his analysis and found that a company's size, profitability and liquidity represent a negative correlation with the failure probability. Also, he found that the company's gearing is positively correlated with the failure probability.

Also, Chen and Shimerda (1981) reviewed 26 articles that classified 65 financial ratios incorporated in predictive studies between 1966 and 1975 , and selected 41 financial ratios that were considered to be important. Emphasizing the importance of using financial ratios in the analysis, they found that, by using the financial ratios, the accuracy of the prediction of a company's bankruptcy exceeds $90 \%$.

Anyway, we can classify the business performance as follows (Achim \& Borlea, 2014): the accounting-based measure of financial performance (represented by Return on assets, Return on equity, Leverage ratio; Flexibility and so on) and the market-based measure of financial performance (represented by Market capitalization; Price to book ratio; Market to Book ratio, Price Earnings ratio, Dividend Yield ratio, Tobin's $Q$ and so on). Even if the effect of variables other than those accounting-based measure on the probability of bankruptcy is already proven (by macroeconomic variables, market-based measure variables, corporate governance variables, etc.), recent research revealed that financial variables are still considered significant variables for the company's performance, providing the majority influence on bankruptcy risk probability (Achim \& Borlea, 2012; 2013; Agraval \& Taffler, 2008; Beaver et al., 2005; Karas \& Režňáková, 2014; Tuvadaratragool, 2013). Moreover, the effects of non-accounting based measure variables ultimately still reflect in financial performances (increase of sales, increase of net income, increase of wealth and so on). These results are also supported by the findings of Beaver et al. (2005) which reflect that "marketbased variables are not a substitute for the accounting-based information but rather a proxy for the predictive power attainable by capturing the total mix of information, including both the financial statement and non-financial statement information." Therefore, the marketbased measure variables include many other influences other than reflecting the internal performance and ultimately they also go- back within the value of accounting basedmeasure. So, based on the literature review, the accounting-based measure variables finally seem to be the best in reflecting the business performances.

\subsection{Review of Used Methodologies}

The development of predictive business failure models was the subject of numerous researchers' studies. Since 1968, the primary methods that have been used for model development are the multivariate discriminant analyses (MDA), developed by Altman (1968; $1970 ; 2005 ; 2006)$ and Beaver (1966; 1968; 2005; 2010).

Ohlson (1980) criticizes the MDA, especially the restrictive statistical requirements imposed by the model and introduces for the first time the logistic regression method meant to better predict the company's failure. The benefits of the logistic regression method are subsequently recognized by many authors, the major advantage being that while the MDA model calculates a bankruptcy score using a linear function, the Logit model predicts that probability as a "dichotomous dependent variable that is a function of a vector of explanatory variables" (Aziz \& Dar, 2006). In their large survey, Bellovary et al. (2007) found that the multiple discriminant analysis is the most common method of predicting bankruptcy risk, being used in $36 \%$ of the investigated studies. On the second place (with 25\%) are the Logit and Probit models.

Later, other methods supported the development of bankruptcy risk prediction models as alternatives to the two models mentioned above: neural networks, hazard model, distance to default cox regression.

\subsection{Limits of Failure Prediction Models}

The interest in developing some bankruptcy risk models was manifested by researchers from the whole world; they would be applied not only to developed countries but also to the emerging countries, too. For developed countries, among the most important bankruptcy risk studies, we can mention: Beaver (1966), Altman (1968; 2005; 2006), Ohlson (1980), Shumway (2001) (for US), Christidis and Gregory (2010) (for UK). For developing countries from Central and Eastern Europe, we can mention: Dominiak and Mazurkiewicz (2011) (Poland), Šarlija and Jeger (2011) (Croatia); Dun and Bradstreet 
(2014), Karas and Režňáková (2013; 2014), Pitrova (2011) (Czech Republic); Elenkov and Fileva (2006) (Bulgaria); Szeverin and László (2014) (Hungary); Ugurlu and Aksoy (2006) (Turkey); Anghel (2002), Siminica (2010), Robu and Mironiuc (2012) (Romania). For developing countries from Asia we note the studies of Wang and Campbell (2010) (China), Suntraruk (2010; 2013) and Tuvadaratragool (2013) (Thailand); Lee W-C (2007) and Lee M-C (2014) (Taiwan).

Despite the efforts of globalization and convergence the economies around the world, there are still large disparities between the world's countries' national economies that make impossible the existence of a global model of assessing bankruptcy risk. A complex survey conducted by Platt and Platt (2008) in three global regions namely Asia (including Australia), Europe and the US highlights that international differences in accounting rules, lending practices, management skills' levels and legal requirements have determined the rejection of the null hypothesis that assumed that a single global model would explain financial distress on each region in favour of a fully relaxed model which created individual financial distress models for each region. Some similar studies were conducted by Laitinen and Suvas (2013) on a sample of 30 European countries and their findings highlighted the significant differences in the shape and power of predicting bankruptcy risk models influenced by characteristics specific to each country, like: economic environment, company status classification and coding systems, legislation and culture. On the same level, Altman and Hotchkiss (2006) also highlighted the most important differences between emerging and developing markets, like currency vulnerability, industry risk, and competitive position and take these factors into account to develop a bankruptcy risk assessment model specifically for emerging economies under the Emerging Market score (EMS) Model.

A limited category aimed to create the models from the investors' perspective. Their demands are different from those of other decision-makers, therefore the results could not be used for a general purpose, but for a specific one. In this regard, Wang and Campbell (2010) in their study on Chinese Publicly Traded Companies analysed which financial indicators have a significant impact on a company's delisting state from the stock. They found that negative own equity and a negative net income for the last two years are the two most influential variables in failure prediction from the investors' perspective. By using this perspective, Christidis and Gregory (2010), in their survey on the companies listed on the London Stock Exchange, identified eight variables as being significant for the companies' risk failure, such as: liquidity indicators (working capital over total assets, quick assets over current assets), profitability (change in net income, a dummy variable equal to one if net income was negative for the last two years, earnings before interest and tax over share capital), cash flow, funds-flow and leverage (measured by total liabilities over total assets). For the Asian stock market, more specifically for Thailand's stock market, Tuvadaratragool (2013) identified eight statistically significant ratios such as: three ratios (current assets to current liabilities, quick assets to current liabilities and working capital to total assets) in the liquidity group; two ratios (sales to total assets and sales to inventory) in the turnover group; two ratios (earnings before interest and tax to interest and total equity to total liabilities ) in the leverage group and one ratio (net income to total assets) in the profitability group. Investigating the above results, it cannot be established that the variables would have a significant impact on stock market delisting.

Such limitation of bankruptcy risk models' application in space and time is highlighted by many authors such as Balcaen and Ooghe (2006) or Cîrciumaru (2011). For instance, Cîrciumaru (2011) also remarked that even for the same economy, the periods of economic instability affect the failure predictions' results and therefore it is necessary to regularly update the models in order to capture the new economic and financial conditions. We can add here that even if the bankruptcy prediction models are created specifically from the investors' perspective, they significantly differ from country to country, from one working methodology to another, from the period in which these models were created (if they were created in a period of economic growth, the results no longer apply to those from the period of economic crisis) etc.

\section{Methodology}

\subsection{Sample and Data}

In this study, the choice of the two groups of companies is made from the investors' 
point of view on the stock market. As long as a company is delisted, it becomes worthless for the investor because a trading platform no longer exists. Even if the company, being delisted, will continue to operate for a period of time, "the shareholders have essentially lost their investment" (Wang \& Campbell, 2010).

For our study a firm is identified as failed if it is delisted from the Bucharest Stock Exchange. Otherwise, if the firm is listed, it is identified as non-failed.

The statistic population consists in 88 large non-financial companies that are traded on Bucharest Stock Exchange at the end of 2013. Banks and other financial institutions are excluded from the study because their financial statements are prepared on a different basis from those of industrial firms (Bryant, 1997; Charitou, Neophytou, \& Charalambous, 2004; Flagg, Giroux, \& Wiggins Jr., 1991; He \& Kamath, 2006; Ohlson, 1980; Tuvadaratragool, 2013). Further, the non-financial companies belong to different area of business such as: industry, commerce, construction and accommodation.

From the sample of 88 non-financial companies, we have identified 65 listed companies and 21 delisted companies. The companies listing on the Bucharest Stock Exchange is classified on three categories (Tier 1, Tier 2 and Tier 3) according to their performances, as follows (Bucharest Stock Exchange, "Issuer's guide of Stock and bonds", 2010):

- Tier 1 includes the companies which have an equity value at least of 30 million EURO in the last financial year and have obtained a net profit in the last two years of activity. We have 16 non-financial companies, at the end of 2013.

- Tier 2 includes the companies which have an equity value at least of 2 million EURO in the the last financial year. We have 48 nonfinancial companies, at the end of 2013.

- Tier 3 includes the companies which have an equity value at least of 1 million EURO in the the last financial year. We have only one companies, at the end of 2013.

A special category of companies traded on the Bucharest Stock Exchange is represented by delisted companies. Delisting means the removal of a listed company from the Bucharest Stock Exchange, voluntarily or involuntarily, because it is not anymore in compliance with the listing requirements of the Bucharest Stock Exchange (no longer qualified for listing, in none of the above mentioned categories). At the end of 2013 there are 21 delisted companies.

Based on economic and statistical reasons, we will withhold in the "Listed" category only those companies that meet the highest performance criteria. More specifically, from the total sample of listed companies (65 companies) we retain only those listed in Tier 1 (namely, 16 companies).

The statistical reasons on which the decision of establishing the samples for bankruptcy risk's prediction analysis relied, aim the balance between the two samples. Although there is a common defaulters' share of less than $10 \%$ in the entire database, this imbalance can lead to large default prediction errors. Marqués, García and Sánchez (2013) mentioned in their study the problem of imbalanced data and found that the use of resampling methods could consistently improve the performance given by the original imbalanced data. Many studies focused on these aspects and used balanced samples in their risk failure studies: Beaver $(1966 ; 1968)$ used 79/79, Altman (1968) used 33/33, Deakin (1972) used 32/32, Bei and Liu (2005) used 31/31, Hossari (2007) used 247/247, Ugurlu and Aksoy (2006) used 27/27, He and Kamat (2006) used 20/20, Tuvadaratragool (2013) used 14/14.

The economic reasons for choosing the two samples are based on the fact that the Tier 1 consists of those companies that meet the most rigorous performance requirements and under these circumstance the likelihood that financial performance variables to be more sensitive to the two non-failure/failure states, is higher.

Finally, our study will be conducted based on two samples: a non-failed sample which consists in 16 listed companies and a failed companies sample which consists in 21 delisted companies. Our two samples are homogeneous, on the one hand, in terms of the companies' size (we consider only large companies) and, on the other hand, in terms of the performed activity (we only sample the companies with an economic profile and therefore the financial institutions are not included).

The data were collected from the companies' annual financial statements, between 2002 and 2012, which are available on the site of the Bucharest Stock Exchange (www.bvb.ro). For the delisted firms, financial data up to two years 
prior to delisting were used in our analysis. For the listed firms, we used the financial data from the last 3 years, namely between 2010 and 2012. The result was of 90 observations.

\subsection{Method of Work}

The dependent variable $\mathrm{Dn}$ is a binary variable: Dn $=1$ for the stock delisted companies; $\mathrm{Dn}=0$ for the stock listed companies. Since the dependent variable is binary, the binary models were used for identifying the delisting probability (bankruptcy risk), which was modelled to depend on regressors. The index function formulation explains an unobserved continuous random variable $y^{*}$ (latent variable), but all we observe is the binary variable $y$, which takes the 1 or 0 value according to whether $y^{*}$ crosses a threshold or not. Different distributions for $y^{*}$ lead to different binary outcome models. Let $y^{*}$ be an unobserved variable. The regression model for $y^{*}$ is the index function model (Cameron \& Trivedy, 2009):

$$
y^{*}=\boldsymbol{X}^{\prime} \beta+u
$$

where the regressor vector $\mathbf{X}$ is a $\mathrm{K} \times 1$ column vector with jth entry $X$, the parameter vector $\beta$ is a $\mathrm{K} \times 1$ column vector with jth entry $\beta_{j}$, and the error vector $\mathrm{u}$ is $\mathrm{a} \mathrm{K} \times 1$ column vector with jth entry $u_{j}$. Let a vector of data denoted as $X_{i}=\left(X_{1 i}, \ldots, X_{k i}\right)$ from $\mathrm{N}$ observations. Then $X^{\prime} \beta=\beta_{1}^{l i} X_{1}+\beta_{2} X_{2}+\ldots+\beta_{k} X_{k}$. The model (1) cannot be estimated because $y^{*}$ is not obseved. We have

$$
y=\left\{\begin{array}{l}
1 \text { if } y^{*}>0, \\
0 \text { if } y^{*} \leq 0,
\end{array}\right.
$$

where the zero threshold is a normalization. Given the latent-variable models (1) and (2) we have

$$
\operatorname{Pr}(y=1 / X)=F\left(X^{\prime} \beta\right)
$$

where $\mathbf{F}\left(\mathbf{X}^{\prime} \beta\right)$ is the cumulative distribution function (c.d.f.) of - u. We obtain the Probit model if $u$ is standard normally distributed and the Logit model if $u$ is logistically distributed. Given the model (3), a more relevant form with conditional probability is given by

$$
p_{i} \equiv \operatorname{Pr}\left[y_{i}=1 / X\right]=F\left(X_{i} \beta\right)
$$

For binary models, the maximum likelihood estimator (MLE) is natural estimator, because the density is unambiguously the Bernoulli. For a sample $(y i, X i), \mathrm{i}=1, \ldots, \mathrm{N}$, of $\mathrm{N}$ independent observations, $\mathrm{ML}$ estimation, $\hat{\beta}$, maximizes the associated log-likelihood function. The $\hat{\beta}$ is obtained by iterative methods and is asymptotically normally distributed. The Wald test and the likelihood-ratio (LR) test are used to produce the test statistics and $p$-value for a test of the significance of individual coefficients, the confidence intervals for individual coefficients, and the tests of overall significance. In the statistics literature a very common interpretation of the coefficients is in terms of marginal effects. We are interesting in determining the marginal effect of change in a regressor on the conditional probability that $y=1$. For general model (3) and change in the jth regressor, assumed to be continuous, this is

$$
\frac{\partial \operatorname{Pr}\left(y_{i}=1 / X_{i}\right)}{\partial x_{i j}}=F^{\prime}\left(\boldsymbol{X}_{i} \beta\right) \beta_{j^{\prime}}
$$

The marginal effects differ with the point of evaluation $\boldsymbol{X} i$. In measuring marginal effects we calculate the change in the probability $\operatorname{Pr}(y=1)$ when regressors change by one unit. Marginal effects of logit variables are estimated. A measure of goodness of fit in the linear regression model is $R^{2}$. The genaralizations to nonlinear models are called pseudo- $R^{2}$. This measure is not always computable but it is for the binary outcome model. This yields the $R^{2}$ measure for binary models proposed by McFadden. We used a good guide (Cameroon \& Trivedy, 2009) that explains how an econometrics computer package such as Stata, may perform regression analysis of a qualitative binary variable.

Based on investigating the aforesaid findings, at the initial stage, we considered 12 financial ratios. These variables are grouped as follows:

A. Profitability

1. Return on assets $=$ Net results $/$ Total assets (ROA)

2. Return on equity $=$ Net results $/$ Own Equity (ROE)

3. Net profit margin $=$ Net results $/$ Sales (NPM)

B. Leverage

4. Leverage ratio $=$ Debt $/$ Shareholder's equity (LEV)

5. Stability ratio $=$ Engaged capital $/$ (Own equity + Liabilities) (STAB) 
C. Liquidity and solvency
6. Current liquidity ratio $=$ Current assets $/$ current liabilities $(\mathrm{CL})$
7. Flexibility ratio $=$ Net working capital/ Total assets (FLEX)
8. Cash-flow/Net results (CWR)
9. General solvency $=$ Total assets/Total debts (SOLV)

D. Activity

10. Assets turnover = Sales/Total assets (ASTU)

11. Current assets turnover $=$ Sales/Current assets (CASTU)

12. Current debts turnover $=$ Sales/Current debts (CDTU)

The correlation results between the selected variables are provided in the following table:

\section{Tab. 1: Correlation matrix}

\begin{tabular}{l|r|r|r|r|r|r|r|r|r|r|r|r} 
& \multicolumn{1}{|c|}{ ASTU } & \multicolumn{1}{c|}{ SOLV } & FLEX & LEV & STAB & CL & ROE & NPM & CASTU & CDTU & CWR & ROA \\
\hline ASTU & 1.0000 & & & & & & & & & & & \\
\hline SOLV & -0.2375 & 1.0000 & & & & & & & & & & \\
\hline FLEX & -0.0834 & 0.4034 & 1.0000 & & & & & & & & & \\
\hline LEV & 0.0282 & -0.1392 & -0.0381 & 1.0000 & & & & & & & & \\
\hline STAB & -0.2812 & 0.4932 & 0.8176 & 0.0171 & 1.0000 & & & & & & & \\
\hline CL & -0.1746 & 0.7191 & 0.5288 & -0.1046 & 0.3730 & 1.0000 & & & & & & \\
\hline ROE & 0.0636 & 0.0802 & 0.1509 & -0.8210 & 0.0110 & 0.1045 & 1.0000 & & & & & \\
\hline NPM & 0.2374 & 0.0376 & 0.0436 & 0.0342 & 0.0454 & -0.0726 & -0.0291 & 1.0000 & & & & \\
\hline CASTU & 0.4965 & 0.1032 & -0.2161 & 0.0974 & -0.0438 & -0.3046 & -0.1060 & 0.2146 & 1.0000 & & & \\
\hline CDTU & 0.3071 & 0.6486 & 0.4163 & 0.1043 & 0.4103 & 0.5649 & 0.1111 & 0.2434 & 0.3610 & 1.0000 & & \\
\hline CWR & 0.3433 & -0.0825 & 0.0169 & 0.0044 & -0.0239 & -0.0441 & -0.0294 & 0.0280 & 0.1868 & 0.0755 & 1.0000 & \\
\hline ROA & 0.1310 & 0.1122 & 0.4706 & -0.0042 & 0.4088 & 0.0888 & 0.1559 & 0.5755 & 0.0113 & 0.3122 & -0.0327 & 1.0000 \\
\hline
\end{tabular}

Source: own calculations

With a few exceptions, which we will consider, Table 1 shows no strong correlation among the ten variables which are mentioned above. They can be used together as potentially explanatory variables in any order or in any combination. From the selected variables, in terms of the information's impact, three models are considered to be relevant to the probability of stock exchange delisting. It is well known that either Logit and Probit models can be used for identifying the variables that are significant and have predictive power, because they have similar shapes for central values of $F($.$) but$ differ in the tails as $F($.$) approaches 0$ or 1 .

\section{Empirical Results and Discussions}

Empirical results of Model 1, Model 2 and Model 3 are provided in the following. The McFadden's $\mathrm{R}^{2}$ marginal effects and the percentage of correctly classified observations provide the explanatory power of variables in models.

\section{Model 1}

The results of the Logit model are presented in Table 2. All regressors, FLEX, ASTU and CASTU are statistically different from zero at the 0.05 level. The null hypothesis that the coefficients of FLEX, ASTU and CASTU are zero is rejected at the 0.05 level. This is confirmed by the LR test. The sign of the coefficient is also the sign of the marginal effect presented in Table 3.

The variables FLEX and CASTU have negative coefficients which means that increasing the flexibility and also the turnover in current assets conduct to a decrease of the probability of delisted $\operatorname{Pr}(\operatorname{Dn}=1)$. Both coefficients have an expected signs (negatives) meaning that by assuring an adequate value of working capital and a high ratio of replacing the current assets by turnover activity, a well efficiency in operating activity is performed. To the contrary, the variable ASTU has a positive coefficient, means that increasing the turnover in total assets conduct to an increase of the 
Tab. 2: Logistic regression

\begin{tabular}{c|r|r|r|r|r|r} 
Dn & \multicolumn{1}{|c|}{ Coef. } & Robust Std. Err. & \multicolumn{1}{c|}{$\mathbf{z}$} & \multicolumn{1}{c|}{$\mathbf{P}>|\mathbf{z}|$} & \multicolumn{2}{|c}{ [95\% Conf. Interval] } \\
\hline FLEX & -3.66313 & 1.508794 & -2.43 & 0.015 & -6.62032 & -0.70595 \\
\hline ASTU & 4.38998 & 1.232050 & 3.56 & 0.000 & 1.97521 & 6.80475 \\
\hline CASTU & -1.08176 & 0.369810 & -2.93 & 0.003 & -1.80658 & -0.35695 \\
\hline _cons & -0.89814 & 0.491670 & -1.83 & 0.068 & -1.86181 & 0.06552 \\
\hline
\end{tabular}

Number of obs. $=90$

Wald chi2 $(3)=12.93$

Prob $>$ chi2 $=0.0048$

Log pseudolikelihood $=-39.891217$

Pseudo $R^{2}=0.3585$

probability of delisting. By taking account the above comments, it is means that the small value of the fixed assets cause problem of disinvestment, conducting to increase of the probability of delisting. We will comment in details all these results after we run all the considered models.

For the fitted Logit model the McFadden's $R^{2}$ is 0.3585 . Table 2 shows a good model of the impact of FLEX, ASTU and CASTU on $\operatorname{Pr}(D n=1)$.

Table 3 provides an estimate of the marginal effect at $\mathrm{X}=\bar{X}$. Among the three stock exchange delisting determinants, flexibility ratio
(FLEX) shows that it has the highest negative marginal impact on dependent variable $(D n=1)$ and assets turnover (ASTU) has a high positive marginal impact. An important point to note is that for the marginal of all three Logit variables i.e. FLEX, ASTU and CASTU on Dn, stock exchange delisting is statistically significant with a significant level of $0.015,0.00$ and respectively 0.003 and they contribute with $52.59 \%$ to the probability of stock exchange delisting. The marginal effect of the model's predictive power on stock exchange delisting is of 0.5259 i.e. $52.59 \%$.

\section{Tab. 3: Marginal effects after Logit}

\begin{tabular}{|c|c|c|c|c|c|c|c|}
\hline \multirow{2}{*}{$\begin{array}{l}\text { Variable } \\
\text { FLEX }\end{array}$} & \multirow{2}{*}{$\begin{array}{c}\mathbf{d y} / \mathbf{d x} \\
-0.91332\end{array}$} & \multirow{2}{*}{$\begin{array}{r}\text { Std. Err. } \\
0.36985\end{array}$} & \multirow{2}{*}{\begin{tabular}{l|}
$\mathbf{z}$ \\
-2.47
\end{tabular}} & \multirow{2}{*}{$\begin{array}{r}P>|z| \\
0.014\end{array}$} & \multicolumn{2}{|c|}{ [95\% Conf. Interval] } & \multirow{2}{*}{$\begin{array}{c}\mathbf{X} \\
0.07215\end{array}$} \\
\hline & & & & & -1.63822 & -0.18842 & \\
\hline ASTU & 1.09454 & 0.29883 & 3.66 & 0.000 & 0.50885 & 1.68024 & 0.84165 \\
\hline CASTU & -0.26971 & 0.09048 & -2.98 & 0.003 & -0.44704 & -0.09238 & 2.24492 \\
\hline $\begin{array}{l}=\operatorname{Pr}(D n) \\
=0.52591\end{array}$ & ct) & & & & & & \\
\hline
\end{tabular}

Source: own calculations

One measure of goodness of fit is the percentage of correctly classified observations. For the fitted Logit model, we obtain Table 4.

Table 4 compares fitted and actual values. The percentage of correctly specified values is of $83.33 \%$. In this Table, 5 observations are misclassified as 1 (stock exchange delisted) when the correct classification is 0 (stock exchange listed), and 10 values are misclassified as 0 (stock exchange listed) when the correct value is 1 (stock exchange delisted).
In the following, we present Model 2 and Model 3 compared to Model 1, to show the insignificant impact of some variables considered at the initial stage.

\section{Model 2}

Assets turnover (ASTU) represents the determining factor of the probability of stock exchange delisting. Table 1 shows no strong correlation among ASTU and CDTU. The results of the Logit model with ASTU and CDTU 
Logistic model for Dn

\begin{tabular}{c|c|c|c}
\hline & \multicolumn{2}{|c|}{ True } & \\
\hline Classified & D & $\sim D$ & Total \\
\hline+ & 32 & 5 & 57 \\
\hline- & 10 & 43 & 90 \\
\hline Total & 42 & 48 & \\
\hline Correctly classified & \multicolumn{3}{|c}{$83.33 \%$} \\
\hline
\end{tabular}

Source: own calculations

as the regressors are presented in Table 5. The null hypothesis that the coefficients of ASTU and CDTU are zero is rejected at the 0.05 level. The sign of the coefficient is also the sign of the marginal effect presented in Table 6 . As in the model 1 , the coefficient of variable ASTU is also positive (we comment on this). As for the variable CDTU, the negative coefficient has an economic significance, meaning that a higher ability of a company to pay its debts, the smaller is the probability of delisting. McFadden' $R^{2}$ is 0.2960 . Table 5 shows a good model of the impact of regressors on the delisting probability $\operatorname{Pr}(D n=1)$, but a smaller than that from Model 1 .

The marginal effects of two Logit variables i.e. ASTU and CDTU on Dn, is statistically significant and they contribute with a probability of $51.83 \%$ to stock exchange delisting.

The percentage of correctly specified values (presented in Tab. 7 ) is with $80 \%$ smaller than that from the first model. The predictive power of the model on the stock exchange delisting doesn't change significantly.

\section{Tab. 5: Logistic regression}

\begin{tabular}{c|r|r|r|r|r|r} 
Dn & \multicolumn{1}{|c|}{ Coef. } & \multicolumn{1}{c|}{ Robust Std. Err. } & \multicolumn{1}{c|}{$\mathbf{z}$} & \multicolumn{2}{c|}{$\mathbf{P}>|\mathbf{z}|$} & \multicolumn{2}{c}{ [95\% Conf. Interval] } \\
\hline ASTU & 3.44703 & 1.02342 & 3.37 & 0.001 & 1.44115 & 5.45291 \\
\hline CDTU & -0.36271 & 0.15072 & -2.41 & 0.016 & -0.65812 & -0.06731 \\
\hline cons & -1.53414 & 0.47610 & -3.22 & 0.001 & -2.46729 & -0.60099 \\
\hline
\end{tabular}

Number of obs. $=90$

Wald chi2 $(2)=11.83$

Prob $>$ chi2 $=0.0027$

Log pseudolikelihood $=-43.774824$

Pseudo $R^{2}=0.2960$

Source: own calculations

\section{Tab. 6: Marginal effects after logit}

\begin{tabular}{|c|c|c|c|c|c|c|c|}
\hline Variable & $\mathrm{dy} / \mathrm{dx}$ & Std. Err. & $\mathbf{z}$ & $P>|z|$ & \multicolumn{2}{|c|}{ [95\% Conf. Interval] } & $\mathbf{x}$ \\
\hline ASTU & 0.86060 & 0.25191 & 3.42 & 0.001 & 0.366874 & 1.35433 & 0.84161 \\
\hline CDTU & -0.09055 & 0.03737 & -2.42 & 0.015 & -0.163803 & -0.01731 & 3.56632 \\
\hline $\begin{array}{l}=\operatorname{Pr}(D n) \\
=0.5183\end{array}$ & lict) & & & & & & \\
\hline
\end{tabular}




\section{Logistic model for Dn}

\begin{tabular}{c|c|c|c}
\hline & \multicolumn{2}{|c|}{ True } & Total \\
\hline Classified & $\mathrm{D}$ & $\sim \mathrm{D}$ & 36 \\
\hline+ & 30 & 6 & 54 \\
\hline- & 12 & 42 & 90 \\
\hline Total & 42 & 48 & \\
\hline Correctly classified & \multicolumn{3}{c}{} \\
\hline
\end{tabular}

Source: own calculations

Observation. If in Model 2 NPM and LEV are added, the model indicates that there is no statistically significant improvement in the results.

Which is the ROE variable's impact on the probability of stock exchange delisting? In order to explain this, we will introduce in Model 2 the ROE variable.

\section{Model 3}

Table 8 indicates that at the 0.05 level, the coefficient of ROE is not statistically significant ( $p$ value $=0.349<0.05)$. The impact of ROE variable on $\operatorname{Pr}(D n=1)$ is not significant. The signs of the coefficients of variables ASTU and CDTU are the same as in the two previous models (positive and respectively negative) and are statistically significant.

From Tables 9 and 10 we can conclude that Model 3 doesn't significantly improve the results obtained in Model 1.

\section{Tab. 8: Logistic regression}

\begin{tabular}{c|r|r|r|r|r|r} 
Dn & \multicolumn{1}{|c|}{ Coef. } & \multicolumn{1}{c|}{ Robust Std. Err. } & \multicolumn{1}{c|}{$\mathbf{z}$} & \multicolumn{2}{c|}{$\mathbf{P}>|\mathbf{z}|$} & \multicolumn{2}{|c}{ [95\% Conf. Interval] } \\
\hline ASTU & 3.49977 & 1.07377 & 3.26 & 0.001 & 1.39521 & 5.60432 \\
\hline ROE & 0.42666 & 0.45532 & 0.94 & 0.349 & -0.46575 & 1.31907 \\
\hline CDTU & -0.37770 & 0.16096 & -2.35 & 0.019 & -0.69319 & -0.06222 \\
\hline cons & -1.52037 & 0.47563 & -3.20 & 0.001 & -2.45260 & -0.58814 \\
\hline
\end{tabular}

Number of obs. $=90$

Wald chi2 $(3)=11.23$

Prob $>$ chi2 $=0.0105$

Log pseudolikelihood $=-43.50051$

Pseudo $R^{2}=0.3004$

Source: own calculations

\section{Tab. 9: Marginal effects after logit}

\begin{tabular}{|c|c|c|c|c|c|c|c|}
\hline Variable & $\mathrm{dy} / \mathrm{dx}$ & Std. Err. & $z$ & $P>|z|$ & \multicolumn{2}{|c|}{ [95\% Conf. Interval] } & $\mathbf{x}$ \\
\hline ASTU & 0.87343 & 0.26357 & 3.31 & 0.001 & 0.35684 & 1.39003 & 0.84161 \\
\hline ROE & 0.10648 & 0.11344 & 0.94 & 0.348 & -0.11586 & 0.32882 & 0.01176 \\
\hline CDTU & -0.09426 & 0.03984 & -2.37 & 0.018 & -0.17235 & -0.01617 & 3.56632 \\
\hline $\begin{aligned} y & =\operatorname{Pr}(\mathrm{Dn}) \\
& =0.520\end{aligned}$ & & & & & & & \\
\hline
\end{tabular}


Tab. 10: The percentage of correctly classified observations

\begin{tabular}{c|c|c|c}
\hline \multicolumn{5}{|c}{ Logistic model for Dn } \\
\hline Classified & D & $\sim D$ & Total \\
\hline+ & 30 & 5 & 35 \\
\hline- & 12 & 43 & 55 \\
\hline Total & 42 & 48 & 90 \\
\hline Correctly classified & \multicolumn{3}{c}{} \\
\hline
\end{tabular}

Source: own calculations

Several general observations: In other variables combinations as well, the ROE variable's impact is not significant. By adding the SOLV, STAB and CL variables, the coefficients are not statistically significant at the level 0.05. Also, in each of the three models, the impact of ROA and CWR is insignificant at the 0.05 level. The difference between the same coefficient of ASTU variable, as it is estimated in Model 2 and Model 3, do not significantly differ. The difference is significant between the same value estimated in Model 1 and any of the other two models. It is normal that the impact of ASTU on the delisting probability $\operatorname{Pr}(D n=1)$ vary depends on the circumstances of the factors considered in each model.

In summary, Model 1 provides the highest explanatory power. Three variables such as Flexibility ratio (FLEX), Assets turnover (ASTU) and Current assets turnover (CASTU) are found to be significant determinants for listing on the stock exchange. These three variables provide $52.59 \%$ of correct prediction of bankruptcy risk and the percentage of correctly classified observations for the fitted Logit model is that of $83.33 \%$. In other words, more than half of the variables significant for bankruptcy risk belong to an accounting-based measure indicators type (three in number) and the other half is due to other factors: market-based indicators, market transactions' volume, corporate governance, corporate social responsibility, etc. In addition to the financial information needs reflected in the financial reports, there is a more acute need for extra-financial information, characteristic of the information needs related to the new economy. Therefore, the study conducted by the consulting company Mc Kinsey (2001) on the view of institutional investors from emerging countries (Asia, Eastern Europe and Latin
America) on corporate governance, reveals that investors pay at least the same importance to non-financial information on corporate governance like that to financial information that their decisions are based on. Given that non-financial information get increasingly more attention in the last decade (see Achim \& Borlea, 2013, p. 83), our results support the significant importance of a company's financial performance reported to its overall performance, this fact being reflected in the company's survival on the market.

In what the models' accuracy is regarded, similar studies conducted to similar percentages with those that we obtained. For the capital markets of Asia and Pacific, Chi and Tang (2006) found a percentage of correctly specified values of $85 \%$. In Thailand, by applying the Logit model, the classification's accuracy rate recorded a result of up to $86 \%$. For Turkey, Uğurlu and Aksoy (2006) found a higher percentage of correct classification of $95.6 \%$ and the predictive results of the Logit model are 94.5 percent (a number of 11 predictors of distress were found to be significant, therefore the addition of one more variable contributes to explain variance by 8.6 percent). In comparison, our study reveals a much higher percent of 17.5 explaining the variance by one of variables.

Regarding the variables that we found out to be representative for our model, we consider our findings for Romania to be both aligned to other findings and also spectacular and original, at least for the following three reasons:

\section{The First Reason Regarding the Variables' Nature}

Analysing the nature of the variables with significant impact on delist risk, we can conclude that they are represented only by activity ratios 
(ASTU and CASTU) and liquidity ratios (FLEX). Our study did not select any indicator of return or leverage as having a significant impact on the delisting risk.

Our results though, are partially aligned with similar studies conducted for the emerging countries, like in Croatia by Šarlija and Jeger (2011). By comparing financial distress prediction models before and during recession in Croatia, by using data from 2006 until 2009, they also found that activity ratios represent the majority group for predicting the financial distress' likelihood (three ratios belong to the activity group, namely Total Revenues/Total Assets, Total Revenues/Short-term Assets and Short-term Assets-Inventory)/Sales). Similar studies were conducted in Turkey by Ugurlu and Aksoy (2006), who found that activity variables (Sales/Current assets, Sales/Fixed assets, Sales/Net working capital) have a significant impact on delisting.

Returning to our study, the insignificant impact of leverage ratios on the delisting risk found by our study could be explained as an atypical behaviour that the Romanian companies adopt concerning the leverage decision. According to the study conducted by Brendea (2014) from 2004 to 2011, the Romanian companies' behaviour in attracting external sources is negatively correlated with the amount of fixed assets which is contradiction with the findings obtained for developed countries (eg, Germany, France and Italy) and more advanced developing countries (e.g. the Czech Republic and Estonia), but are in line with a country similar to Romania, namely Bulgaria. As a result of this atypical behaviour of the listed companies concerning the financial structure, it cannot "predict" accurately a company's delisting and our results are therefore supported by these findings.

By making a comparison with other studies conducted in Romania, our variables' nature differ significantly with those from other studies on bankruptcy risk (Anghel, 2002; Robu-Mironiuc, 2012; Siminica, 2010). Only one variabile, namely Current Assets turnover (CASTU) is identified in other studies as well, namely in that conducted by Siminică (2010). However, in none of the studies mentioned in Romania has been developed a bankruptcy prediction model from the investors' perspective, namely the risk of delisting. As shown in our study, companies can have high rates of profitability but there is a possibility that a financial distress reflected in the company's stock exchange delisting to be unpredictable. Moreover, neither the financial structure indicators (e.g. Leverage ratio) seem to be capable of predicting such a delisting, as previously mentioned.

\section{The Second Reason Regarding the Type of Variables}

If we especially refer to the types of variables that were selected in our study, our results are in line with various similar findings. Therefore, FLEX variable is an highly encountered indicator in studies from different emerging countries like Thailand (Tuvadaratrogol, 2013) but also in studies from developed countries like US (Altman 1968; 2005; Ohlson 1980) or UK (Christidis \& Gregory, 2010).

Referring to the ASTU or CASTU ratios of activity that were identified as having a significant impact on the delisting risk, in Turkey, Ugurlu and Aksoy (2006) found similar variables for a company's delisting probability and Chi and Tang (2006) making a bankruptcy risk study in seven capital markets from Asia and the Pacific (Hong Kong, Japan, Korea, Malaysia, Singapore, Thailand and the Philippines) they identified the Fixed Assets turnover ratio as having a significant impact in predicting bankruptcy.

\section{The Third Reason Regarding the Sign of the Coefficients}

For two of the three resulted variables, specifically for FLEX and CASTU the results are aligned with the expectations based on the economic theory. The variables' coefficients are negative and in terms of marginal effects reflect as an increase by one unit of the company's flexibility (FLEX) and respectively of current assets turnover (CASTU) conducting to a decrease in the delisting probability. The results based on the economic theory are as expected. By analysing the indicators' averages, we found that the average for FLEX for non-failed firms is of 0.1422 compared to the negative values of -0.007 for failed firms. Also the average of CASTU for non-failed firms is of 2.21 compared with a lower value of 0.1449 for failed firms.

The third variable, ASTU Assets turnover (ASTU) has a positive coefficient, fact that reflects that the higher the total assets' turnover rate, the bigger is the possibility of a bankruptcy 
(in our case delisting). The result is contrary to the expectations based on the economic theory. Indeed, returning to our results, the Assets turnover's average (ASTU) for nonfailed firms is of 0.5487 compared with 1.1763 for failed firms. By further analysing the active components, we can conclude that for the nonfailed companies the average of Fixed assets turnover is significantly lower than that of failed firms (a value of 2.29 for listed companies compared with a value of 3.18 for delisted companies). This is the main cause because of which the non-failed firms have a 0.63 lower Assets turnover average compared to that of the failed firms. Trying to find some explanations regarding these results that contradict the economic theory, we continued the analysis and found that, on average, the Fixed Assets/ Current Assets report for failed firms is significantly lower than that for non-failed firms (0.93 for delisted companies compared with 1.71 for listed companies). Thus, it is reflected a lower ratio of Fixed Asset in total assets for failed firms (in average of $48.18 \%$ ) comparing with that of non-failed firms $(63.15 \%)$. In other words, disinvestment of the failed firms was the main cause that led to a more pronounced degree of replacement of Fixed Assets by turnover and not to a higher efficiency of their use.

The results are in line with those obtained for other developing countries (Turkey, AsiaPacific countries, Taiwan). In Turkey, Ugurlu and Aksoy (2006) identified Current assets turnover as having a negative impact on failure probability and Fixed assets turnover as having a positive impact on failure probability. Generally, the higher these ratios are, the more efficient is the firm's utilization of these assets. For fixed assets, as it is the case with our study, the theory is not validated. The mean of the fixed assets turnover is significantly higher for the failed firms implying that "these firms have low investment in fixed assets and/or are using highly depreciated assets". Chi and Tang's study (2006) attested for Asia and the Pacific's capital markets similar findings regarding fixed assets turnover, which reflected a higher level of fixed turnover, leading therefore to a higher risk of failure. For Taiwan, Lee (2014) found also a positive impact of Fixed assets turnover on the probability of failure.

On the other hand, our results contradict the findings of Altman (1968; 2005; 2006) and Taffler (1983) conducted for developed countries (US). They found that an increase in assets turnover should lead to a decrease in the probability of bankruptcy (the results are within the theory). We also found in literature many other opposite findings to the theoretical approach in the area of failure risk model. For instance, for Thailand (Tuvadaratragol, 2013), according to the indicators' marginal effect, one unit increase in liquidity (represented by quick assets to current liabilities and also by working capital to total assets) will cause an increase in the probability of financial distress, which is against the theory of financial ratios' analysis. He explained these findings according to the applied methodologies and noted that "this characteristic is quite often encountered in the case of Logit-based studies". But, this explanation is not very well assessed since, by using other models, the results could be also contrary. For instance, in Taiwan, Lee (2007), as a result of applying Genetic Programming Decision Tree, found that the coverage ratio has a positive impact on failure probability. Later, by applying the Hazard model, he found fixed asset turnover, capital turnover and price to book value as having a positive impact on failure probability. In other emerging country (Turkey), by applying both MDA and Logit analysis, Ugurlu and Aksoy (2006) found the gross profit margin as being one of the most important financial distress' predictors, the coefficient being positive. They explained the findings which were contrary to the theoretical expectations, as being "higher costs of production and/or lower levels of sales" of the failed firms which could conduct to higher gross profit margin ratios comparing to the non-failed firms. Finally, they explained the causes for which the coefficients' signs of some significant predictors are contrary to the expectations reflecting "problems of the economic system" of the emerging markets such as Turkey.

We could accept the reasons for some against theory findings as being revelatory for the emerging economies' problems, if we wouldn't identify similar studies conducted in developed countries which reject our hypothesis. For instance, a study on corporate Failure conducted in the US for the manufacturing Industries by Darayseh, Waples and Tsoukalas (2003) revealed some against theory findings. They found that net profit margin has a positive impact on the failure risk. They explained these findings as "profit margin on sales being 
a "measure of profitability position in the shortrun", the profitability variables "would be more important over the short and long-term".

However, we identified results opposite to the economic theory in greater measure among emerging countries than in the developed countries, fact that still sustains the hypothesis on the explanation of such against theory results and that is, that they are based on in transition economy systems, which still face great deficiencies compared to the developed ones. Moreover, compared to similar East Central European countries (Poland, Czech Republic, Hungary) the capital market in Romania (on which this study was based) is a young one, recording major shortcomings in the main market indicators, such as: Low liquidity and a pronounced imbalance between the traded instruments' share (for operations).

\section{Conclusions}

A number of 37 firms, 16 listed and 21 unlisted on the stock exchange were examined in order to determine the significant variables in predicting stock exchange delisting via Logit Model. 12 variables were used in estimating three alternative Logit models for determining their signs, significance, predictive power, goodness of fit tests. Model 1 provided the highest explanatory power. Three variables such as Flexibility ratio (FLEX), Assets turnover (ASTU) and Current assets turnover (CASTU) were found to be significant determinants for a company's listing on the stock exchange.

These three variables provided a bankruptcy risk correct prediction of $52.59 \%$, the rest being attributed to factors different than accountingbased measure indicators, such as: corporate governance, corporate social responsibility, the auditor's opinion, stock exchange transaction, macroeconomic factors etc. The percentage of correctly classified observations for the fitted Logit model is of $83.33 \%$.

The results are largely in line with those obtained for emerging markets, but also we emphasized the specific of the results in bankruptcy risk as a consequence of the investor's view perspective.

Therefore, we revealed that the model's features are generated by the Romanian economy's specific and thus the Romanian capital market, which is a young market with great flaws in key market indicators (low liquidity, low informational efficiency, reduced funding on the capital market for the Romanian companies etc). These are the system deficiencies that led to some results that are contrary to the expectations based on the economic theory such as those on Assets turnover, which show a positive impact on failure probability. On the other hand, according to the expectations generated by the economic theory, Current assets turnover and Flexibility ratio represent a negative impact on failure probability. In line with the authors' opinions (Altman, 1968; 2005; 2006; Taffler, 1983; Walton et al., 2003), it is important that financial ratios of a specific business to be best interpreted as a group, because the interpretation of a single financial ratio can provide an altered image at a specific moment.

This paper is intended to be an original material because of the elaboration for the first time in Romania of a financial failure model intended to be of use to investors on the capital market by providing necessary clues on the upcoming shares' delisting on the stock exchange, a time when from the investors' point of view the company is already bankrupt. Studying bankruptcy from the investors' point of view is a rather rarely treated subject in the literature (compared to other legal and economic approaches) and in Romania it is the first study of this kind. Thus, our research can bring added value to current research in the field of bankruptcy risk, coming to cover a gap on the niche of developing some bankruptcy risk models from the investors' perspective.

As future research perspective, we consider trying to identify the bankruptcy predictors for other emerging countries' capital markets (Czech Republic, Poland, Hungary and Bulgaria) from the investors' perspective and analyse possible differences from Romania.

\section{References}

Achim, M. V., \& Borlea, N. S. (2014). Environmental performances - way to boost up financial performances of companies. Environmental engineering and management journal, 13(4), 991-1004.

Achim, M. V., \& Borlea, N. S. (2013). Corporate governance and business performances. LAP Lambert Academic Publishing Germany.

Achim, M. V., \& Borlea, N. S. (2012). Consideration on business risk bankruptcy. 
Review of Economic Studies and Research Virgil Madgearu, 5(2), 5-29.

Altman, E. I. (1968). Financial Ratios, Discriminant Analysis and the Prediction of Corporate Bankruptcy. Journal of Finance, 23(4), 589-609. doi:10.2307/2978933.

Altman, E. I. (2005). An Emerging Market Credit Scoring System for Corporate Bonds. Emerging Markets Review, 6(4), 311-323. doi:10.1016/j.ememar.2005.09.007.

Altman, E. I., \& Hotchkiss, E. (2006). Corporate Financial Distress and Bankruptcy: Predict and Avoid Bankruptcy, Analyse and Invest in Distress Debt (3rd ed.). John Wiley and Sons.

Agraval, V., \& Taffler, R. J. (2007). Twentyfive years of the Taffler z-score model: does it really have predictive ability? Accounting and Business Research, 37(4), 285-300. doi:10.10 80/00014788.2007.9663313.

Anghel, I. (2002). Bankruptcy Radiography and Predilection. Bucureşti: Economic Publishing House.

Aziz, M. A., \& Dar, H. A. (2006). Predicting Corporate Bankruptcy: Where We Stand? Corporate Governance, 6(1), 18-33. doi:10.1108/14720700610649436.

Balcaen, S., \& Ooghe, H. (2006). 35 Years of Studies on Business Failure: An Overview of the Classic Statistical Methodologies and Their Related Problems. The British Accounting Review, 38(1), 63-93. doi:10.1016/j. bar.2005.09.001.

Beaver, W. H. (1966). Financial Ratios as Predictors of Failure. Journal of Accounting Research, 4(7), 1-111. doi:10.2307/2490171.

Beaver, W. H., McNichols, M. F., \& Rhie, J. W. (2005). Have Financial Statements Become Less Informative? Evidence from the Ability of Financial Ratios to Predict Bankruptcy. Review of Accounting Studies, 10(1), 93-122. doi:10.1007/s11142-004-6341-9.

Beaver, W. H., Correia, W. H., \& McNichols, M. F. (2010). Financial statement analysis and the prediction of financial distress. Foundations \& Trends in Accounting, 5(2), 99-102. doi:10.1561/1400000018.

Brendea, G. (2014). Financing Behaviour of Romanian Listed Firms in Adjusting to the Target Capital Structure. Czech Journal of Economics and Finance, 64(4), 312-329.

Bucharest Stock Exchange. (2010). Issuer's guide of Stock and bonds. Retrieved from http://www.bvb.ro/info/Ghid\%20admitere\%20 BVB\%20iunie\%202010.pdf.
Cameron, A. C., \& Trivery, P. K. (2009). Microeconometrics Using Stata. College Station, TX: A Stata Press Publication, StataCorp LP.

Chen, K. H., \& Shimerda, T. A. (1981). An Empirical Analysis of Useful Financial Ratios. Financial Management, 10(1), 51-60.

Chi, L. C., \& Tang, T. C. (2006). Bankruptcy Prediction: Application of Logit Analysis in Export Credit Risks. Australian Journal of Management, 31(1), 17-27. doi:10.1177/031289620603100102.

Christidis, A. C., \& Gregory, A. (2010). Some New Models for Financial Distress Prediction in the UK (Xfi - Centre for Finance and Investment Discussion Paper No. 10). Exeter: University of Exeter, Business school. doi:10.2139/ ssrn. 1687166.

Circiumaru, D. (2011). The score models for analysing the bankruptcy risk. Some specific features for the case of Romania. The Young Economic Journal, 1(16), 153-160.

Darayseh, M., Waples, E., \& Tsoukalas, D. (2003). Corporate Failure for Manufacturing Industries Using Firms Specifics and Economic Environment with Logit Analysis. Managerial Finance, 29(8), 23-36. doi:10.1108/03074350310768409.

Elenkov, D., \& Fileva, T. (2006). Anatomy of a business failure: Accepting the "bad luck" explanation vs. proactively learning in international business. Cross Cultural Management, 13(2), 132-141. doi:10.1108/13527600610662311.

Karas, M., \& Reznakova, M. A. (2014). Parametric or nonparametric approach for creating a new bankruptcy prediction model: The evidence from the Czech Republic. International Journal of Mathematical Models and Methods in Applied Sciences, 8(1), 214223.

Lee, M. C. (2014). Business Bankruptcy Prediction Based on Survival Analysis Approach. International Journal of Computer Science and Information Technology, 6(2), 103119. doi:10.5121/ijcsit.2014.6207.

Lee, W. C. (2007). Improving Financial Distress Prediction via Genetic Programming Decision Tree-Evidences form Taiwan. Journal of Statistics and Management Systems, 6(12), 1129-1149. doi:10.1080/09720510.2009.10701 447.

Laitinen, K., \& Suvas, A. (2013). International Applicability of Corporate Failure 
Risk Models Based on Financial Statement Information: Comparisons across European Countries. Journal of Finance and Economics, 1(3), 1-26. doi:10.12735/jfe.v1i3p01.

Marqués, A., García, V., \& Sánchez, J. S. (2013). On the suitability of resampling techniques for the class imbalance problem in credit scoring. Journal of the Operational Research Society, 64(7), 1060-1070. doi:10.1057/jors.2012.120.

Ohlson, J. A. (1980). Financial Ratios and the Probabilistic Prediction of Bankruptcy. Journal of Accounting Research, 18(1), 109131. doi:10.2307/2490395.

Platt, H. D., \& Platt, M. B. (2008). Financial distress comparison across three global regions. Journal of Risk and Financial Management, 1(1), 129-162. doi:10.3390/jrfm1010129.

Pitrová, K. (2011). Possibilities of the Altman Zeta model application to Czech firms. E\&M Ekonomie a Management, 14(3), 66-76.

Robu, M., Mironiuc, M., \& Robu, I. B. (2012). A practical model for testing the hypothesis of "going-concern" in the financial audit mission for Romanian listed companies. Revista Audit Financiar, 2, 13-23.

Šarlija, N., \& Jeger, M. (2011). Comparing financial distress prediction models before and during recession. Croatian Operational Research Review, 2(1), 133-142.

Siminica, M. (2010). Financial diagnosis. Publishing House SITECH.

Shumway, T. (2001), Forecasting Bankruptcy More Accurately: A Simple Hazard Model. Journal of Business, 74(1), 101-124. doi:10.1086/209665.

Szeverin, E. K., \& Laszlo, K. (2014). The Efficiency of Bankruptcy Forecast Models in the Hungarian SME Sector. Journal of Competitiveness, 6(2), 56-73. doi:10.7441/ joc.2014.02.05.
Todea, A., \& Lazar, D. (2012). Global Crisis and Relative Efficiency: empirical evidence from Central and Eastern European Stock Markets. The Review of Finance and Banking, 4(1), 45-52.

Tuvadaratragool, S. (2013). The role of financial ratios in signalling financial distress: evidence from Thai listed companies (Doctoral dissertation). Lismore: Southern Cross University (http://epubs.scu.edu.au/cgi/ viewcontent.cgi ?article=1291\&context=theses).

Ugurlu, M., \& Aksoy, H. (2006). Prediction of corporate financial distress in an emerging market: the case of Turkey. Cross Cultural Management: An International Journal, 13(4), 277-295. doi:10.1108/13527600610713396.

Wang, Y., \& Campbell, M. (2010). Financial ratios and the prediction of bankruptcy: The Ohlson model applied to Chinese publicly traded companies. The Journal of Organizational Leadership and Business, 17(1), 334-338.

Assoc. Prof. Phd. habil. Monica Violeta Achim Babeş-Bolyai University Faculty of Economics and Business Administration monica.achim@econ.ubbcluj.ro monicaachim@yahoo.com

Assoc. Prof. Phd. Sorin Nicolae Borlea Phd. West Vasile Goldis University Faculty of Economics, Informatics and Engineering snborlea@yahoo.com

Economist Phd. Lucian Vasile Găban "1 Decembrie 1918" University Faculty of Economics Alba Iulia luciangaban@yahoo.com 


\title{
Abstract
}

\section{FAILURE PREDICTION FROM THE INVESTORS' VIEW BY USING FINANCIAL RATIOS. LESSON FROM ROMANIA}

\author{
Monica Violeta Achim, Sorin Nicolae Borlea, Lucian Vasile Găban
}

The purpose of our study is to identify which financial indicators have a significant impact on the probability of Romanian companies' bankruptcy risk from the investors' point of view by studying the impact on the probability of shares delisting from the stock exchange. The research is conducted on a sample of 16 failed and 21 non-failed non-financial companies listed on the Bucharest Stock Exchange between 2002 and 2012.

The Logit analysis is used for identifying the variables that are significant and have predictive power on distress likelihood. By using 12 main financial ratios, we estimate three alternative Logit models for determining their signs, significance, predictive power, efficiency of fit tests. The first model provides the highest explanatory power. Three variables such as Flexibility ratio (FLEX), Assets turnover (ASTU) and Current assets turnover (CASTU) are found to be significant determinants for stock exchange delisting. These three variables provide $52.59 \%$ of correct prediction of bankruptcy risk. The percentage for correctly classified observations for the fitted Logit model is of $83.33 \%$.

Moreover, this research attempts to reveal the changes that may appear among bankruptcy predictors given that the bankruptcy risk model is developed from the investors' point of view and not from that of a simple decision-making person. For a stock market investor, bankruptcy already starts at the stage of delisting the company because the investment was strongly compromised, whether or it continues its activity or not. Orientation towards investors when predicting bankruptcy risk is the main element of originality that our research adds to the scientific achievements in bankruptcy, until this moment.

Key Words: Delisting, failure prediction, financial ratios, Logit model.

JEL Classification: C25, C52, G33.

DOI: 10.15240/tul/001/2016-4-009 